\title{
Inheritance of high prolificacy of the Olkuska sheep (preliminary results)
}

\author{
M. J. RADOMSKA ${ }^{1}$, E. MARTYNIUK 1 , J. KLEWIEC ${ }^{2}$ and A. KNOTHE \\ 1 Agricultural University \\ Rakowiecka 12 \\ 02-517 Warsaw, Poland \\ ${ }^{2}$ Institute of Genetics and Animal Breeding PAN \\ Jastrzebiec, 05-551 Mroków, Poland \\ ${ }^{3}$ Agricultural University \\ Al. Mickiewicza 24 \\ 30-059 Cracow, Poland
}

\begin{abstract}
Studies are being conducted on the mode of inheritance of high reproductive performance of the Olkuska $(\mathrm{O})$ sheep, a local Polish breed. Ten $\mathrm{O}$ were used in crosses with Polish Merino (PM) ewes. The ovulation rate of $60 \mathrm{~F}_{1}$ ewes $(\mathrm{O} \times \mathrm{PM})$ and 129 pure $\mathrm{PM}$ ewes was stated by means of laparoscopy. The prolificacy of female ancestors, full-sisters and progeny of $3 \mathrm{O}$ rams was extensively analysed.
\end{abstract}

Index words: Olkuska, Polish Merino, ovulation rate, litter size, inheritance

\section{Introduction}

There are five well-known prolific sheep breeds: Finnsheep, Romanov, D'man, Booroola Merino, Cambridge (1). In Poland, studies are being conducted on the mode of inheritance of high reproductive performance of the Olkuska (O) sheep, a local breed (2). Ten $\mathrm{O}$ rams were used in crosses with Polish Merino (PM) ewes. The ovulation rate (OR) of $60 \mathrm{~F}_{1}$ ewes $(\mathrm{O} \times \mathrm{PM})$ and 129 pure $\mathrm{PM}$ ewes was stated by means of laparoscopy. OR of $19 \mathrm{~F}_{1}$ ewes ( 10 months old) was $1-3$, of
41 ewes ( $2-3$ years old) was $1-4$. It was found that $80 \%$ of PM ewes had 1 corpus luteum and $20 \%$ had 2 corpora lutea. The hitherto-obtained results were described by RAdOMSKa et al., (4) and Martyniuk (3).

\section{Experimental and results}

In this paper data concerning 3 rams of the prolific $\mathrm{O}$ breed, which were mated to not prolific $\mathrm{O}$ ewes and to PM ewes, are presented. The litter size (LS) of their female ancestors, their full-sisters and female progeny are list- 
Table 1. Litter size of ram's female ancestors.

\begin{tabular}{lcc}
\hline Ram & \multicolumn{2}{c}{ Maximum litter size: } \\
\cline { 2 - 3 } & Dam & Dam of the sire \\
\hline 7185 & 4 & 5 \\
7182 & 6 & 5 \\
7179 & 3 & 4 \\
\hline
\end{tabular}

ed in Tables $1-3$. The LS of dams, fullsisters and pure $\mathrm{O}$ daughters was based on data from at least 3 first lambings at the age of $1-3$ years.

The lifetime LS records of dams and sire's dams are given in Table 1. Not all full-sisters were prolific (Table 2). The number of daughters from matings with not prolific $\mathrm{O}$ sheep was small, only one daughter of the ram No. 7182 was prolific (Table 2). The LS of crossbred daughters received at the experimental farm of the Institute of Genetics and Animal Breeding Polish Academii of Science are listed in Tables 3. The daughters of ram No. 7182 displayed the highest LS, the daughters of the ram No. 1760 the lowest. The lambing data confirmed the laparoscopy results. The greater number of born lambs stated in one
Table 3. Litter size of $F_{1}$ ewes (Olkuska $\times$ Polish Merino).

\begin{tabular}{|c|c|c|c|}
\hline \multirow[t]{2}{*}{$F_{1}$ ewes } & \multicolumn{3}{|c|}{ Sire: } \\
\hline & 7185 & 7182 & 7179 \\
\hline \multicolumn{4}{|l|}{$\begin{array}{l}\text { I. Two years old } \\
\text { (second pregnancy) }\end{array}$} \\
\hline \multicolumn{4}{|l|}{ Ovulation rate: } \\
\hline number of ewes & 3 & 9 & 5 \\
\hline ovulations/ewe & 1.67 & 2.44 & 1.40 \\
\hline maximum ovulations/ewe & 2 & 4 & 2 \\
\hline \multicolumn{4}{|l|}{ Lambing: } \\
\hline number of ewes & 3 & 9 & 5 \\
\hline mean litter size & 1.67 & 2.33 & 1.60 \\
\hline maximum litter size & 2 & 3 & 2 \\
\hline \multicolumn{4}{|l|}{$\begin{array}{l}\text { II. Three years old } \\
\text { (third pregnancy) }\end{array}$} \\
\hline \multicolumn{4}{|l|}{ Ovulation rate: } \\
\hline number of ewes & 4 & 8 & 5 \\
\hline ovulations/ewe & 2.00 & 2.50 & 2.00 \\
\hline maximum ovulations/ewe & 2 & 4 & 3 \\
\hline \multicolumn{4}{|l|}{ Lambing: } \\
\hline number of ewes & 4 & 5 & 3 \\
\hline mean litter size & 2.00 & 2.00 & 2.00 \\
\hline maximum litter size & 2 & 3 & 4 \\
\hline
\end{tabular}

case, in comparison to OR rate may be due to one-egg twins. The OR of the PM ewes at the same farm was 1.10 , the maximum OR being 2 .

Table 2. Number of full-sisters (mean litter size) and daughters with at least one or with no litter size records of three or more.

\begin{tabular}{|c|c|c|c|c|c|c|}
\hline \multirow[t]{3}{*}{ Ram } & \multicolumn{3}{|c|}{ Full-sisters } & \multicolumn{3}{|c|}{ Daughters } \\
\hline & \multirow[t]{2}{*}{ Total } & \multicolumn{2}{|c|}{$\begin{array}{c}\text { Number with litter size } \\
\text { records } \geqslant 3\end{array}$} & \multirow[t]{2}{*}{ Total } & \multicolumn{2}{|c|}{$\begin{array}{c}\text { Number with litter size } \\
\text { records } \geqslant 3\end{array}$} \\
\hline & & At least one & None & & At least one & None \\
\hline 7185 & 4 & $3(2.70)$ & $1(1.67)$ & 3 & - & $3(1.70)$ \\
\hline 7182 & 4 & $1(2.25)$ & $3(1.33)$ & 1 & $1(2.75)$ & - \\
\hline 7179 & - & - & - & - & - & - \\
\hline
\end{tabular}

\section{References}

1. BINDON, B.M. \& PIPER, L.R. 1986. Genetic Engineering of Animals ed. V. Evans and A. Hollaender Plenum Press, London: 67-93.

2. Grabowski, W., Klewiec, J., Knothe, A. \& Radoms. KA, M.J. 1987. Animal Genetic Resources. FAO Anim. Prod. \& Health Paper No. 66, Rome: 259
-260 .

3. Martyniuk, E. 1988. 3rd World Congr. Sheep \& Beef Cattle Breed. Paris, 2: 688-690.

4. Radomska, M.J., Grabowski, W., Knothe, A. \& KLeWIEC, J. 1987. 38th Ann. Meet. EAAP, Lisbon. 